\title{
Why history and philosophy of science matters
}

\section{Luciano Boschiero ${ }^{1}$}

Published online: 11 February 2020

(c) Springer Nature B.V. 2020

This is my last editorial for Metascience as I conclude my 5-year term as co-editor. With this announcement, I would also like to introduce the new co-editor taking my place, Jonathan Simon from the Université de Lorraine, France.

Dr Simon is well qualified for the job, with experience working in the USA, Australia, England, and France, specialising in the history of pharmacy. He has also served on the Editorial Board of Metascience for many years and has regularly assisted in the commissioning of reviews. While Dr Simon will take over the editorial tasks associated mostly with books to do with the history of science, Dr Brad Wray will continue as co-editor for philosophy of science books. They will share responsibility for reviews of books in the broad category of social studies of science and technology. It pleases me immensely to know that as I step down from my role as editor, these two excellent scholars - themselves well-recognised authors-with a wide interest in the literature produced in our field, will continue to carry the journal to new heights. Ably supported by Lori Nash, Assistant Editor, and an encouraging team at Springer, Metascience remains in very good hands indeed.

There are many people I would like to thank for their support over the last 5 years. The staff at Springer have always been very generous with their time, resources, and assistance. In particular, Eric Pieren, Catherine Murphy, Jos Walbeek as Production Co-ordinators, and Lucy Fleet and Ties Nijssen as Publishing Editors. This venture would obviously not succeed without their hard work and support for the journal.

The members of the Editorial Board have been very valuable to me in the search for reviewers and in the identification of suitable books for review. I wish to thank them for their assistance and for their continued dedication to Metascience.

I also wish to thank the previous editors of Metascience. The list-too long to include here-stretches back to the first issue in 1984 and then under the auspices of the Australasian Association for the History, Philosophy, and Social Studies of Science (AAHPSSS), which continues to give its support to the journal. Though there are many past editors responsible for the journal's success, I would like to single out John Forge, whose kind words of encouragement and guidance I have greatly appreciated. I will, additionally, name our more immediate predecessors: Stathis Psillos,

Luciano Boschiero

1.boschiero@campion.edu.au

1 Campion College, Sydney, Australia 
Theodore Arabatzis, and Steven French, who served as mentors during times of transition and who left the journal well positioned in its goal to deliver diversely structured quality book reviews serving the varied interests of historians, philosophers, and sociologists of science. Brad and I were very fortunate to inherit such a rich legacy and I would like to think that the journal has continued to thrive under our editorship —ultimately, however, that is for our readers to judge.

It is my firm belief that the strength of this journal and the collegiality of the community of scholars it serves, is evidenced by the fact that its past editors continue to contribute to its pages. For example, in this issue, it is rather fitting that Brad Wray's latest book, Resisting Scientific Realism (Cambridge, UK: 2018), is reviewed in a symposium by two of the afore-mentioned editors, Stathis Psillos and Steven French. I'm sure that the readers will appreciate the quality of the discussion between these reviewers, including the contributions of Kyle Stanford and Peter Vickers.

Last but not least, I would like to thank you: Metascience's reviewers over the past 5 years; book authors who have consulted us about the possibility of a review; and, of course, the community of scholars that make up the readership. Reviewers invest a great deal of time and effort to provide the content that fills the journal's pages, and our readers also choose-from among all the other options for reading material available online and in print- to give us their time and attention. I am greatly appreciative of this, and I think it is another testament to the strengths of our community and the quality of Metascience's reviews. I will miss hearing from you all as regularly as I have, but I hope at some point I will cross paths with each of you.

As these are my departing words as co-editor, I would like to indulge in some broad reflections on the state of our field and on the relevance of Metascience. These reflections are based largely on my acknowledgement, above, of the strength of our field. They may also reflect the Australian context in which I have worked for most of my career, more so than the experiences of readers in other parts of the world.

I recall my first perusal of an issue of Metascience. I was a senior undergraduate student steadily being drawn into the prospect of an academic career. I immediately identified the unique qualities of the journal. In no other regular publication could I find so many contributions from so many of the best-known authors in the historical, philosophical, and sociological studies of science. Not only were the authors well known to scholars in the areas of STS, HPS, and SSK, but they were willing to share, in this journal, their views on the latest publications on a wide range of topics. Other journals, I thought, had their merits, but they each have their specialised niches and their highly specialised research articles. Metascience, it occurred to me then, caters for everyone's interests. It still does.

This realisation boosted my desire to participate in this community, to become a contributor to Metascience - not just for the free books, but to mix in that exalted company. It helped me believe that this field has a unique position in academia, explaining its rich past and its promising vibrant future. That optimism was also based on what I recognised as the far-reaching relevance of the combined areas of history, philosophy, and sociology of science. As was taught by the great historians and philosophers of science of the early- and mid-twentieth century—such as 
George Sarton, I. Bernard Cohen, Pierre Duhem, and Alexander Koyré—and by the renowned writers of the SSK movement of the mid-to-late twentieth century, we are able to bridge the divide between the natural sciences and the humanities. This takes us far beyond what scholarship on either side of the humanities-science divide could offer on its own, in terms of our understanding of the world around us. For example, where knowledge of environmental change is dominated by either scientific reports listing facts about climate change or impassioned political activism, historians, philosophers, and sociologists of science are able to pull back the veil for each of these attempts at truth-telling and work towards a deep understanding of the contributions of each participant to the debate; historically, how the knowledge has evolved; philosophically, the development of the different arguments; and sociologically, how the participants have deployed and refined their strategies in efforts to persuade others. In short, through critical historical, sociological, and philosophical analyses of a major scientific dispute, we can trace the source of our divisions and possibly contribute to future resolutions.

As such, we do not see science just as the depository of truth and politics as the domain of rhetoric and power, each operating in a separate sphere and interacting only to interfere in each other's area of expertise. Instead, we see the cultural filtera term often used in our field to denote the participants' attitudes, training, political sensitivities, and theory-laden observations - through which all parties perceive and engage with the world. In the process, as David Pepper wrote on this seemingly intractable debate about climate change, using the tools at our disposal as historians and philosophers, we "enlarge the scope of our present thinking." (David Pepper, Roots of Modern Environmentalism, London: Croom Helm, 1984, 11). Coincidentally, Pepper made this point in the same year that Metascience published its first issue, and it is a good example of why history, philosophy, and sociology of science matter. It is a point that still holds true today. In sum, ours is a broad field of study that bridges divides and attempts to see further than other academic specialties.

My admiration for the rich history of the field and my enthusiasm for what it can offer, remain strong today. Unfortunately, however, my optimism for the future of the field, at least in Australia, has diminished. At my alma mater, the University of Wollongong, the few historians and philosophers of science that remain are facing extinction. The same may be said for the university where I completed my postgraduate studies, the University of New South Wales; while in other universities, the relevance of history and philosophy of science in modern education is routinely questioned. In our defence, we deploy the same arguments - similar to those I made above-we know to be true, but they are either not heard, ignored, or not understood by university administrators who measure relevance according to profitability, rankings, and graduate employability data. Graduates from our field typically go into a myriad of different sectors-education, law, medicine, politics, etc.-but those outcomes are not immediately achieved after graduation or are attributed solely to subsequent specialist degrees. The skills of critical thinking, effective communication, and problem-solving which are nurtured within our field-and in liberal education more broadly-remain with our graduates for their entire careers, most of which relate to science and technology in some way, shape, or form. But these virtues remain under-valued by our university executives. 
Notwithstanding these difficulties, there is still some hope for the future. Academics in our field, now dispersed across different generically titled departments, still produce brilliant scholarship. There are many liberal arts colleges and research networks across the globe that are mindful of the need to step into this gap that has now opened up in many universities. There are also many other universities that still promote the field through the strength of their faculty and their library collections. And there are still journals and professional associations that help bind these communities together; this is precisely what AAHPSSS was aiming to do so many years ago when it started this journal. Now, in this rather challenging environment in which we need to defend the relevance of our field, Metascience is arguably more important than ever.

As co-editor of Metascience for the past 5 years, I have been in a position to see just how diverse and significant our field can be and what it can achieve-from an understanding of our intellectual roots - globally, not just in the West - to an appreciation of the ways in which the sciences operate today and the currency of scientific expertise that often shapes our communities. Noone can deny the importance of each and every one of those books and the value of the critiques that have accompanied their release in the pages of Metascience. While I am now wary about the future of our academic field, at least in Australia, I remain optimistic about the future of this journal and I look forward to seeing it continue to promote the excellent work done in history, philosophy, and the social studies of science.

Publisher's Note Springer Nature remains neutral with regard to jurisdictional claims in published maps and institutional affiliations. 